\title{
Non-JUSTIFICATIONISM AND THE NEGATIVIST LEGEND ABOUT KARL POPPER'S PHILOSOPHY
}

\author{
Dmytro Sepetyi
}

\begin{abstract}
This paper discusses the meaning of non-justificationism as an important part of Karl Popper's philosophy of critical rationalism and William Bartley's philosophy of pancritical rationalism. Construals and attempted developments of critical rationalism by David Miller and Alan Musgrave are analysed and critically evaluated. The case is made that Miller's rejection of the relevance of reasons for rationality runs counter to Popper's view and is not supported by Popper's and Bartley's non-justificationist arguments. Besides, it is untenable because rationality cannot be reduced to the validity of arguments plus truth-value attributing «decisions» but essentially involves weighing up reasons for and against available options. With respect to Musgrave's construal of non-justificationism and critical rationalism as the view that believing a proposition is rational if the proposition best survives critical scrutiny, it is argued that it is vulnerable to the problem of the infinite regress of criticizers (positions with which the scrutiny is to be carried out). The case is made that Popper's-Bartley's non-justificationism is to be understood as the identification of rationality with the openness to critical discussion in the search for truth and the claim that such discussion does not require ultimate unrevisable foundations, although it necessarily involves positions that are accepted for the purposes of the argument at hand without being provided with justification. In the perspective of critical rationalism, such positions play the role similar to that of «immediate knowledge» of classical rationalism and empiricism; however, unlike the latter, they are considered as fallible, open to examination, and revisable.
\end{abstract}

Keywords: critical rationalism, non-justificationism, reasons, revision, belief.

\section{НОН-ДЖАСТИФІКАЦІОНІЗМ І НЕГАТИВІСТСЬКА ЛЕГЕНДА ПРО ФІЛОСОФІЮ КАРЛА ПОППЕРА}

\begin{abstract}
Анотація. У статті обговорюється значення неджастифікаціонізму як важливої частини філософії критичного раціоналізму Карла Попера та панкритичного раціоналізму Вільяма Бартлі. Здійснюється аналіз та критична оцінка тлумачень та спроб розвитку критичного раціоналізму, запропонованих Девідом Мілером та Аланом Масгрейвом. Обгрунтовується думка, що заперечення Мілером релевантності підстав для раціональності суперечить поглядам Попера і не підтримується аргументацією Попера
\end{abstract}

Актуальні проблеми духовності:

зб. наук. праць / Ред.: Я.В. Шрамко. -

Кривий Ріг, 2020. - Вип. 21. - С. 24-45. 
й Бартлі, що лежить в основі неджастифікаціонізму. Крім того, це заперечення $є$ неприйнятним, оскільки раціональність неможливо звести до коректності аргументів та «рішень» щодо визнання обговорюваних положень істинними чи хибними; для неї необхідне зважування підстав на користь та проти наявних альтернатив. З'ясовується, що тлумачення Масгрейвом неджастифікаціонізму та критичного раціоналізму як погляду, згідно якого прийняття пропозиції $є$ раціональним, якщо ця пропозиція найкраще витримує критичне оцінювання, є вразливим перед проблемою нескінченного регресу положень, на основі яких має здійснюватися це оцінювання. Пропонується й обгрунтовується розуміння неджастифікаціонізму Попера та Бартлі як концепції, що ототожнює раціональність з відкритістю до критичної дискусії в пошуках істини та наголошує, що хоча така дискусія й потребує прийняття певних положень без їх обгрунтування, як непроблематичних або правдоподібних для сторін дискусії, ці положення не мають розглядатися як непорушний фундамент, що не може бути ревізований. В перспективі критичного раціоналізму, такі положення відіграють роль, подібну до ролі «безпосереднього знання» у класичному раціоналізмі та емпіризмі; проте вони розглядаються як такі, що можуть бути помилковими і є відкритими для критичного обговорення й перегляду.

Ключові слова: критичний раціоналізм, неджастифікаціонізм, підстави, ревізія, погляд.

\section{Introduction}

One of the most important and controversial positions of the epistemology of Karl Popper and his followers is called «non-justificationism». The term obviously means the negation of something called «justificationism». The opposition, in these terms, was introduced by Popper's pupil and collaborator William Bartley. In the book Retreat to Commitment ${ }^{1}$, Bartley opposed Popper's critical rationalism and his own purportedly improved version of it, comprehensively critical (pancritical) rationalism, to the dominant traditional notion of rationality he dubbed «justificationism» - the view that for a belief to be rational, it must be justified by sound argument, or by sufficient or good reasons. The relationship between Popper's and Bartley's view of the matter is not quite clear and requires detailed discussion beyond the scope of this paper. What is clear is that Popper had readily accepted the construal of his general conception of rationality, critical rationalism, in terms of the negation of justificationism. Popper's non-justificationism is most explicit and salient in his book Realism and the Aim of Science. ${ }^{2}$ It is worth noting that this book, as well as two other books in the trilogy Postscript to The Logic of Scientific Discovery, was prepared for publication under the editorship of Bartley; probably, this had some influence on the formulations that relate to justification and non-justificationism.

${ }^{1}$ Bartley W. The Retreat to Commitment. - La Salle, Illinois : Open Court, 1984.

${ }^{2}$ Popper K. Realism and the Aim of Science. - London: Hutchinson, 1983. 
Popper's-Bartley's non-justificationism gave rise to controversies in evaluative and interpretative dimensions. With respect to evaluation, most Popperians highly prize non-justificationism, whereas many other epistemologists tend to consider it as unacceptable scepticism, or even irrationalism. With respect to interpretation (that involves also attempts at development), Popper's-Bartley's non-justificationism became a matter of controversy between Popperian epistemologists, especially two of the most prominent, David Miller and Alan Musgrave. In this article, I outline and critically discuss their conceptions of critical rationalism and nonjustificationism, argue that they essentially diverge from Popper's and Bartley's views in ways that make critical rationalism more vulnerable, and elucidate Popper's and Bartley's views on these matters.

The controversies at issue have much to do with what I propose to call «the negativist legend» about Popper's philosophy. (This is a sort of counterpart to «the positivist legend», against which Popper and his followers made so much just complaint.) Roughly, it is that Popper's philosophy is all about negation, falsification, refutation, argument against. In the most unsympathetic versions, the legend is that Popper's philosophy is just a kind of discouraging skepticism, or irrationalism, and that it is preposterously defying common sense. One of the most glaring examples is D. Stove's book Popper and After: Four Modern Irrationalists, in which Popper is claimed to be a modern irrationalist, alongside with Lacatos, Kuhn, and Feyerabend, because «[t]hey doubt, or deny outright, that there can be any reason to believe any scientific theory; and a fortiori they doubt or deny, for example, that there has been any accumulation of knowledge in recent centuries». ${ }^{3}$ Stove's view got approval of the reputed contemporary analytic philosopher David Papineau, in two reviews in Times Literary Supplement. ${ }^{4}$ The view is popularised by Stephen Law in the books The Philosophy Gym (a bestseller that introduces a lay reader to the most important philosophical issues in a very engaging way) and The Great Philosophers. In a chapter of The Philosophy Gym, Law attributes to Popper the view «that we never possess any grounds for supposing that a scientific theory is true». ${ }^{5}$ In The Great Philosophers, Law directly misrepresents

\footnotetext{
${ }^{3}$ Stove D. Popper and After: Four Modern Irrationalists. - Oxford, New York: Pergamon Press, 1982. - p. viii.

${ }^{4}$ Papineau D. Review of Popper and After by David Stove // Times Literary Supplement. - 1983. - July 1; Papineau D. Review of Knowledge and the BodyMind Problem and The Myth of the Framework by Karl Popper // Times Literary Supplement. - 1995. - June 23.

${ }^{5}$ Law S. Philosophy Gym. - London: Headline Review, 2004. - p. 126.
} 
Popper's view - he writes that Popper, in effect, accepts Hume's conclusion that beliefs (1) that tomorrow morning the sun will appear over the horizon and (2) that tomorrow morning a million-mile-wide luminous panda will appear over the horizon are equally reasonable. ${ }^{6}$

\section{David Miller's conception of critical rationalism: doing away with reasons}

Surprisingly, «the negativist legend» seems to find support in the construal of critical rationalism by David Miller, who was a friend and collaborator of Popper and is perhaps the most reputed among Popper's modern followers. ${ }^{7}$ Miller seems to identify justificationism with the view that rationality has something to do with sufficient (conclusive), or good (inconclusive) reasons, or even just reasons. Accordingly, Miller, as a nonjustificationist, goes so far as to deny the existence of both sufficient and good reasons :

The subjective feeling of being in possession of good reasons may exist.

But as far as rational thought is concerned, evaluation in terms of good reasons is a pure epiphenomenon. ${ }^{8}$

Although Miller admits the existence of reasons in the subjective sense, he denies that they may be good, and he denies that reasons have some job to do for rational thought:

Reasons exist, no doubt, at least in the subjective sense, but not good ones [...] But this does not imply that rationality is impossible, either in intellectual affairs or in practice. Reason has a job to do in every sphere; reasons, poor things, have not. ${ }^{9}$

This nearly repeats the statement by David Papineau: «Popper's official doctrine is that we never have any reason to believe that any scientific theory is true» (Papineau $D$. Review of Knowledge and the Body-Mind Problem and The Myth of the Framework by Karl Popper). Although this statement is pretty similar to some things Popper said about reasons for holding a scientific theory to be true (I will dwell on this point a bit later), it is very misleading because taken out of the context and not provided with appropriate explanations and qualifications (which Popper had given).

${ }^{6}$ Law S. The Great Philosophers. - London: Quercus, 2007. - p. 175.

${ }^{7}$ An example of another Popperian author who follows Miller's construal of critical rationalism is Antoni Diller, who attempts to criticise Bartley from these positions. - See Diller A. On Critical and Pancritical Rationalism // Philosophy of the Social Sciences. - 2012. - Vol. 43 (2). - P. 127-156.

${ }^{8}$ Miller D. Critical Rationalism: A Restatement and Defense. - La Salle, Illinois: Open Court, 1994. - p. 66.

${ }^{9}$ Ibid. - p. 52 . 
On Miller's view, the only thing that matters for rationality is criticism, negative argument, attempts to refute a theory.

Miller's contentions, although presented as a restatement of critical rationalism, go far beyond Popper and Bartley. For Popper, for one, it was a perfectly usual and unproblematic thing to claim having weighty, or good, or «more or less sufficient» reasons. Let me adduce some conspicuous examples.

In a lecture delivered at the University of Tübingen in 1981, Popper formulated three «principles that form the basis of every rational discussion, that is, of every discussion undertaken in the search for truth»; one of these principles is «the principle of rational discussion: we want to try, as impersonally as possible, to weigh up our reasons for and against a theory» ${ }^{10}$ (Italics mine). From this, it is clear that Popper believed that there are reasons, both for and against a theory, and that they may be weighed up so that some turn out weightier than others (at least, for a person), and that is just what rationality is about.

In the book Realism and the Aim of Science, Popper formulates another important principle: «we should not depart from common sense [...] without some fairly good reason». ${ }^{11}$ It seems that Miller goes against this principle in two ways: first, he departs from common sense without fairly good reason; second, he denies that there are such things as good reasons.

And Popper repeatedly says that there are good critical reasons (by "critical reasons" he usually means reasons to prefer one theory over another):

We can have good reasons - that is, good critical reasons - for thinking that we have learned something important: that we have progressed toward truth. ${ }^{12}$

I can examine my guess critically, and if it withstands severe criticism, then this fact may be taken as a good critical reason in favour of it. ${ }^{13}$

Miller is not unaware of this. In his later book, Out of Error, he complains that Popper «regrettably, [...] in several places [...] slipped into what look like justificationist theses, saying for example that "we must at least in some cases be able to give reasons for the intuitive claim that

${ }^{10}$ Popper K. In Search of a Better World. - London and New York : Routledge, 1992. - p. 199.

${ }^{11}$ Popper K. Realism and the Aim of Science. - p. 47.

Of course, this principle provides us with no «criteria» or «algorithm», for one needs in each individual case to judge for oneself what accords with, and what departs from, common sense, and what reasons are «fairly good».

${ }^{12}$ Ibid. - p. 25.

${ }^{13}$ Popper K. Conjectures and Refutations. - New York: Basic Books, 1962. - p. 233. 
we have come nearer to the truth, or that some theory $T_{1}$ is superseded by some new theory $T_{2}$, because $T_{2}$ is more like the truth than is $T_{1}$ " (1972, Chapter 2, §7)». ${ }^{14}$ So, Miller sees justificationism even in such a modest claim about requirement in some cases to provide reasons (even without any such adjective as «good») for the preference of one theory over another in terms of nearing the truth. As for «critical reasons» (or «negative reasons»), Miller's view is that Popper was mistaken:

Critical rationalism need have no more truck with negative reasons than it does with positive reasons. There are no negative reasons either; nor do we need them for rational thought and action. ${ }^{15}$

There is one important point in Popper's writings concerned with reasons that may need explanation in order to avoid misinterpretation. It is concerned with a very important kind of statements, the one at the very center of Popper's interest - scientific theories that are, or have as their parts, universal statements (of laws of nature). ${ }^{16}$ About such theories, Popper argued (with reference to Bartley) that it is impossible to justify them by giving ""positive reasons" [...]; reasons, that is, for holding them to be true, or to be at least "probable" (in the sense of the probability calculus)»; ${ }^{17}$ however, «we can often give reasons for regarding one theory as preferable to another» by «pointing out that, and how, one theory has hitherto withstood criticism better than another». ${ }^{18}$ Popper proposed to call such reasons «critical reasons». Two points need to be taken into account here.

The first is that the term «positive reasons» does not mean «reasons for»; it is used by Popper rather to imply ensurance of truth sensu stricto (rather than being a better approximation to the truth, as compared with known alternatives) or high probability (in the sense of the probability calculus).

The second point to be taken into account is that this case concerns scientific theories, and it is not generalizable to all kinds of positions

${ }^{14}$ Miller D. Out of Error. Further Essays on Critical Rationalism. - Aldershot: Ashgate, 2006. - p. 126.

${ }^{15}$ Miller D. Critical Rationalism. - p. 70.

${ }^{16}$ Roughly, a universal statement is a statement that all things of a certain class have a certain conceptually independent property (such that does not belong to the class by definition, is not part of the concept of the class), where the class is open. A class is open if it is (at least, potentially) infinite, and includes all conceptually fitting things that exist, existed, or will ever exist.

${ }^{17}$ Popper K. Realism and the Aim of Science. - p. 19.

${ }^{18}$ Ibid. 
(statements). For example, with respect to a (meta)statement that a certain scientific theory is false, we can have pretty good reasons to believe that the statement is true. Or, if we have pretty weighty reasons to prefer one scientific theory (A) over another (B), we have exactly the same - and, therefore, just as weighty - reasons to believe in the truth of the (meta)statement that $\mathrm{A}$ is better than B. ${ }^{19}$ Outside science, as well as in science with respect to non-universal statements, there are lots of positions such that we can have pretty good reasons to believe them to be true. For example: «The Earth is round rather than cubic», «Donald Trump is the President of USA», «Nazi Germany invaded Poland in 1939 and so unleashed the World War II». In particular, whenever the list of logically possible alternatives is limited and known (for example, «God exists» and «God does not exist»), the reasons to believe a certain position are the same (and, thus, just as weighty) as the reasons to prefer it over the alternative ones.

If we consider Popper's and Bartley's arguments against justificationism, we can see that they have nothing essentially to do with the view that only refutations or «negative» arguments, in the sense of arguments that provide reasons against, matter whereas «positive» arguments, in the sense of arguments that provide reasons for, do not. Thus, Bartley introduced the term «justificationism» in the context of «the problem of the limits of rationality», which is that if we are required to justify our beliefs, we can never do this without appealing to some other beliefs that remain unjustified, and so we can never achieve justification. From this, a lot of philosophers argued that we have no choice but to commit ourselves dogmatically to some foundational framework - «that there is an essential logical limitation to rationality: the rational defense and examination of ideas must, for logical reasons, be terminated by an arbitrary and irrational appeal to what can be called dogmas or absolute presuppositions». ${ }^{20}$ Bartley confronted this view by arguing that «criticism can be carried out successfully and satisfactorily without [...] any resort to dogmas or authorities», that «it is not necessary to mark off a special class of statements, the justifiers, which do the justifying and criticizing but are not open to criticism», ${ }^{21}$ and thus «there

\footnotetext{
${ }^{19}$ Popper admitted this, and pointed out that «there is a world of difference between a meta-theory that asserts that a theory $\mathrm{A}$ is better than a theory $\mathrm{B}$, and another meta-theory that asserts that theory A is, in fact, true (or "probable")», and «there is a world of difference between arguments that might be considered as valid or weighty reasons in support of the one or the other of these two meta-theories» (Ibid. - p. 23).

${ }^{20}$ Bartley W. The Retreat to Commitment. - p. 221.

${ }^{21}$ Ibid. - p. 223.
} 
are no limits to rationality in the sense that one must postulate dogmas or presuppositions that must be held exempt from review». ${ }^{22}$ However, Bartley's talk of «criticism» may happen to be misleading, because we are prone to interpret «criticism» as argument against. ${ }^{23}$ In fact, Bartley's argument has nothing to do with establishing that arguments against are better off than arguments for. It establishes that we can reasonably argue - whether against or for a position - starting with premises that aren't justified, and that we need not commit ourselves to these premises (take them as «dogmas or presuppositions that must be held exempt from review») - instead, we can tentatively accept them as unproblematic, or as plausible enough, as far as we can judge, for the purpose at hand.

To summarize, Popper's and Bartley's non-justificationist arguments do not warrant any of the following contentions.

- (Good, weighty, etc.) reasons do not exist or, if they exist, they «have no job», as far as rationality is concerned.

- The only arguments (reasons) that matter for rationality are those against the statement at issue.

- There are no reasons for holding a statement to be true, for whatever statement.

Popper's and Bartley's non-justificationist arguments demonstrate the following.

- Against justificationist (uncritical) rationalism: The demand that every position, to be rationally accepted, should be justified, is self-

${ }^{22}$ Ibid. - p. 221.

This Bartley's argument can be considered as a generalization of Popper's «Resolution of Fries's Trilemma» in The Logic of Scientific Discovery: although no basic statement is absolutely basic, any can be tested with the use of further basic statements, this procedure of testing should stop somewhere (at a point that is arbitrary from the purely logical point of view) - and it stops «at statements about whose acceptance or rejection the various investigators are likely to reach agreement» (if it was not the case that scientists pretty often agree as to what is observed, science would be impossible) (Popper K. The Logic of Scientific Discovery. - London: Hutchinson, 1959. - P. 104$105)$.

${ }^{23}$ Bartley himself seems to make such a slip and to be the source of this misunderstanding, in describing his proposition to contrast justificationist and nonjustificationist theories of criticism as a generalization of Popper's distinction between verification and falsification (Bartley W. Unfathomed Knowledge, Unmeasured Wealth. - La Salle, Illinois: Open Court, 1990. - p. 237). In fact, non-justificationism is not a generalization of falsificationism (see, however, the previous footnote); it answers an entirely different problem: the problem of infinite justificationist regress and the purported inevitableness of dogmatic commitment is entirely unlike the problem of the possibility of inductive inference and verification; the non-justificationist solution to the former, unlike falsificationist solution of the latter, need not involve «negativism». 
defeating.

- Against irrationalism: Nevertheless, we may - and better do - hold the rationalist attitude, in the sense of being open to critical discussion (aimed at truth) that may make us revise our beliefs.

- Against «the theory of unrevisable-framework-bound rationality» («the commitment theory»): For a rational discussion to be possible and fruitful, we do not need to accept some positions dogmatically, as exempt from critical discussion. Instead, we may proceed on tentative (plausible, in the light of what we presently seem to know) premises.

- Generally: No ultimate, unrevisable foundation is needed for rational discussion.

Of course, the fact that Miller's view about reasons is different from Popper's view does not mean that it is wrong. The detailed enough discussion and criticism of Miller's views require much more space than this paper allows. However, I will make some relevant points here.

Miller complains that it is not clear «what good reasons are supposed to be good for». ${ }^{24}$ I think that the answer is that usually, when the word combination «good reasons» is used, one means reasons that are good enough for the purpose at hand. In epistemological context, the purpose is a (tentative) judgment as to whether the position (statement, or theory) at issue is true, or good enough approximation to the truth, or false and not good enough. This, of course, does not explain what counts as a good reason, or what are the criteria of something being a good reason. Eventually, it is a matter of personal judgment.

It may be objected that evaluation in terms of good reasons is unsatisfactory as subjective and woolly. Why not replace it, as Miller seems to propose, with evaluation in logically neat terms, such as validity of arguments and refutation ${ }^{25} \mathrm{I}$ think that there is a pretty good reason why.

To begin with, there is no sense at all in being interested in providing merely valid arguments. One can always very easily provide valid argument for and against any statement. (The simplest valid argument for any conclusion is a one-premised argument in which the premise is the same as the conclusion.) What we must be interested in is not merely valid but sound arguments, that is, valid arguments with true premises. But how can we know whether the premises are true? Strictly speaking, we

${ }^{24}$ Miller D. Critical Rationalism: A Restatement and Defense. - p. 60.

${ }^{25}$ To my earlier criticisms of his views, Miller answered with an email, where he explained that his point is that we shouldn't be interested in providing «good reasons», but «should be interested in providing valid critical arguments». 
never know, and logics cannot tell us (except for the uninteresting cases of tautologies and self-contradictions). At some points, we should just make our judgments as a matter of informal understanding, or of what just seems to us to be the case, without further argumentative support.

This does not contradict Miller's view, since Miller admitted the necessity of «decisions» or «conjectures» to resolve such conflicts. However, I think that this admission is not sufficient, and the terms «decisions» or «conjectures» are likely to be misleading. ${ }^{26}$ It is not the case that all there is are valid arguments plus «decisions» or «conjectures» as to which statements are to be accepted (classified) as true and which declined (classified) as false. Things are not as simple as that.

The process of reasoning is not a smooth passage from what seems to be - or not to be - the case to valid deductive inferences therefrom. If it were, there would be nothing problematic about it, and there would be no job for philosophy. Miller's claim that in order to classify a hypothesis as false, "[a]ll we need is a false consequence of it" 27 is not helpful either, for we first need to judge whether the consequence is false or true. In the process of reasoning and rational discussion, disagreement arises exactly because (and insofar as) we are forced to choose between alternative positions each of which has consequences that its opponents think to be false (and even its defenders often find problematic and would probably think false if they didn't think that the available alternatives has more clearly false consequences). Logics cannot resolve such a conflict; all it can do is to reveal the conflict and help us see what is involved in it. ${ }^{28}$ When a conflict is revealed, we must judge what is most likely to be the «weaker» position,

${ }^{26}$ The term «decision» is appropriate for actions in which volition is involved, but not for the process of acquiring, holding, and abandoning beliefs. A person can decide to act in a certain way rather than another, but she cannot decide, and implement the decision, to believe this rather than that.

The term «conjecture» is used by critical rationalists in two essentially different senses. There is «conjecture1» as invention of a new idea, or theory, and there is «conjecture2» as a tentative judgment that an idea, or theory, is true, or false, or (un)likely to be a good approximation to the truth. These are very different things; a person can conjecture1 without conjecturing2; conjecture 2 is a judgment that follows conjecture1.

${ }^{27}$ Miller D. Critical rationalism. - p. 70.

${ }^{28}$ Cf.: $\ll$ A valid argument [...] is not so much a proof as a choice. It presents us with a set of mutually exclusive alternatives. [...] Logical arguments, contrary to popular belief, cannot force us to accept the truth of their conclusions. They can force us to choose, but they cannot make the choice for us» (Notturno M. Science and the Open Society. - Central European University Press, 1999. - p. 71-72). «[I]t is judgments of our own that are really necessary. Valid arguments play the extremely important role of clarifying our options. But they cannot make our judgments for us» (Ibid. - p. 146). 
or how we can resolve the conflict with the least loss. Usually, this is not a matter of straightforward intuitive judgment, or mere conjecture (and even less so «decision»), that it is A rather than B that should be renounced as false. Usually, in such conflict situations, judgment is guided by various considerations about what is involved with (renouncing) A, and what is involved with (renouncing) B, and judgments of how plausible and how important the items involved are. So, weighing up of such considerations (reasons) is necessary, and this cannot be reduced to the validity of the arguments.

Another relevant and important point is that considerations (reasons) that are relevant to our judgments (to guide and affect them) are often such that the position they support does not validly (deductively) follow from them. To make sense of this relevance in the form of (deductively) valid argument, additional (bridging) premises are necessary, and these premises should have the form of a statement that describes the conditions when it is reasonable to believe in the truth of propositions of a certain kind, that is, specifies good reasons for believing in the truth of propositions of this kind.

To make it clearer, let us consider the following example. There are alternative theories A and B. As far as we can judge, A has hitherto withstood criticism better than B. From this, we arrive at the judgment that (more likely than not) A is nearer the truth than B. Now let us try to construct a valid argument to that point. First, let us consider the following argument:

A has hitherto withstood criticism better than B.

Therefore, $\mathbf{A}$ is (more likely than not) nearer the truth than $\mathbf{B}$.

This argument is invalid. Now let us consider another argument:

(1) It is reasonable to believe that a theory $\mathbf{A}$ is nearer the truth than an alternative theory $\mathbf{B}$, if $\mathbf{A}$ has hitherto withstood criticism better than $\mathbf{B}$.

(2) A has hitherto withstood criticism better than $\mathbf{B}$.

Therefore, it is reasonable to believe that $\mathrm{A}$ is nearer the truth than B.

This argument is perfectly valid. However, it involves an additional premise that describes the conditions of reasonable belief (that is, what should count as a good reason for believing) that one theory is nearer the 
truth than another. And its conclusion is not that A is nearer the truth than $\mathrm{B}$, but that it is reasonable to believe that $\mathrm{A}$ is nearer the truth than B.

\section{Alan Musgrave's conception and the problem of the infinite regress of criticizers}

Considerations of the kind discussed at the end of the preceding section underlie Alan Musgrave's construal of non-justificationism as the view that theories, or statements, or belief-contents cannot be justified but that belief-acts (such as believing a proposition or preferring one theory over another) can. There are no reasons for (justification of) «S», where «S» is a statement, or a theory, or a belief-content; however, there may be reasons for - we may be justified in - believing that S. ${ }^{29}$

I think that this is right if understood merely in the sense that it is reasonable for a person (given his/her epistemic situation) to believe some propositions and not reasonable to believe some others, and that this reasonability (and rationality) has much to do with looking for reasons and weighing them up.

However, there are more disputable aspects to Musgrave's views on the problem of justification: he holds that for a belief-act to be reasonable there should be good reasons or justification for it ${ }^{30}$, and he attempts to

\footnotetext{
${ }^{29}$ Musgrave A. Common Sense, Science and Scepticism. - Cambridge University Press, 2000. - P. 174-175, 280-282; Musgrave A. How Popper [Might Have] Solved the Problem of Induction // Philosophy. - 2004. - Vol. 79(1). - P. 3-4; Musgrave A. Critical Rationalism // E. Suárez-Iñiguez, ed., The Power of Argumentation (Poznań Studies in the Philosophy of the Sciences and the Humanities, vol. 93). - Amsterdam/New York: Rodopi, 2007. - P. 177-187.

${ }^{30}$ I had an email correspondence with Musgrave, and he wrote, among other things: «To say that a belief is reasonable is to say that there is a reason or justification for it». This assumption is perspicuously implicit in an argument advanced in the article «Experience and Perceptual Belief»: Musgrave explains that «perceptual beliefs are foundational beliefs [...] in the sense that they are not obtained by inference or argument from other beliefs», and then proceeds to argue that experiences should count as (non-logical) reasons for belief-acts, because otherwise «none of our "foundational beliefs", beliefs not obtained by arguing from other beliefs, are reasonable, since there is no reason for them. Add that any belief obtained by arguing from unreasonable beliefs is itself unreasonable, and it follows that all beliefs are unreasonable» (Musgrave A. Experience and Perceptual Belief // S. Parusnikova and R.S. Cohen (eds). Rethinking Popper. - Dordrecht: Springer Science and Business Media, 2009. - p. 13). My point in the discussion that follows is that for this approach to work, we should loosen the requirement for reasonability much more than that - to admit to the class of foundational beliefs an indefinite multitude of non-perceptual beliefs such that the only
} 
construct a comprehensive critical rationalist theory of belief-act justification. I think that he fails in this, because the requirement that beliefacts, to be reasonable, should be justified brings back the initial problem with justification - that of the dilemma of infinite justificatory regress or vicious circle - with no satisfactory solution.

A necessary part of Bartley's solution to this problem was that justification is not required for rationality - in the sense that it is not the case that for any belief to be reasonable, we should be able to provide justification for it. Now Musgrave seems to bring the requirement back, and it does not essentially matter that now it is about belief-acts rather than belief-contents. The justification problem remains essentially the same: to justify your believing that S, you need to refer to some further positions that serve as justifiers, but then you need to justify your believing in those purported justifiers, to provide second-level justifiers for believing in the first-level justifiers, and then third-level justifiers for believing in the second-level justifiers, and so on ad infinitum.

Musgrave attempts to manage the problem in the way that involves the following two major points.

1) On Musgrave's view, critical rationalism is the theory of rationality that assumes, as the most fundamental, the following principle of reasonableness (rationality):

(CR) It is reasonable to adopt the theory that best survives critical scrutiny.

Critical rationalist's justification (reason) for holding critical rationalism is that it fits the principle (CR), that is, it best survives critical scrutiny.

2) Critical rationalism assumes also the following principle:

(P\&T) Perceptual and testimentory beliefs, that is, beliefs acquired from one's own perceptual experiences or from other peoples' testimonies as to what they have observed or experienced or done ${ }^{31}$, are not

reason for believing them is that their content just seems to be the case (to a person).

${ }^{31}$ Musgrave describes the testimentory beliefs as «beliefs acquired from other people» (Musgrave A. Critical Rationalism. - p. 209), which description allows for all sorts of beliefs. On the other hand, the examples he adduces and the very name «the testimentory beliefs» suggest that what he really means are beliefs that derive from other peoples' testimonies as to what they have observed or experienced or done, which is a far more limited class of beliefs. 
required to be justified, or are to be considered as «justified by default», if no weighty reasons are provided against believing them. ${ }^{32}$

However, such a justification raises at least two grave objections. The first, frankly admitted by Musgrave himself:

Self-subsumption is too easy to obtain. «It is reasonable to believe anything said in a paper by Alan Musgrave» subsumes itself, since it occurs in this paper, but it is crazy epistemic principle. So is «Granny told me I ought to believe everything she tells me». And «The Pope declared ex cathedra that everything declared ex cathedra by the Pope is a matter of faith» is no triumph either. ${ }^{33}$

Although this seems to be a very grave objection, Musgrave proposes to «bite the bullet» because, anyway, for obvious logical reasons, no theory of rationality (reasonableness) can do anything better, in order to justify its own acceptance, than to appeal to those criteria of rationality (reasonableness) that this theory itself takes to be the most basic. If it appealed to some other criteria, it would contradict itself (what it says about the criteria of reasonableness), and the rationalist cannot tolerate self-contradiction. Even if self-subsumption is too easy to obtain, it is, at least, a necessary (though not sufficient) condition for a theory to be rationally acceptable (that is, its absence is a sufficient condition to rule out the theory as rationally inacceptable).

For me, it seems that such a poor purported justification - one that provides just as good reason for believing CR as my granny's claim that everything she tells me is true provides for my believing this her claim

${ }^{32}$ Ibid. - pp. 200-202, 206-209.

In (P\&T) I have conjoined two principles, as formulated by Musgrave:

(E) «It is reasonable to perceptually believe that $\mathrm{P}$ (at time $\mathrm{t}$ ) if and only if $\mathrm{P}$ has not failed to withstand criticism (at time t)» (Ibid. - p. 207)

and

(T) «A's testimentory belief that $\mathrm{P}$ is reasonable (at time $\mathrm{t}$ ) if and only if $\mathrm{P}$ has not failed to withstand criticism from A (at time t)» (Ibid. - p. 209).

In other papers, Musgrave makes nearly the same point as (E) by proposing that the reasons for believing a statement need not necessarily be (believing in) other statements; instead, they may be perceptual experiences (Musgrave A. How Popper [Might Have] Solved the Problem of Induction. - P. 4-6; Musgrave A. Experience and Perceptual Belief. - p. 13). For example, my seeing a cat is a good reason (justifier) for my believing that there is a cat.

${ }^{33}$ Musgrave A. Critical Rationalism. - p. 190. 
- is not to be considered as justification, or anything even remotely like good reason. It would be at least more honest for a critical rationalist to admit that she believes CR (or some further considerations in its favor that she can perhaps summon up) with no justification, or reason, except that it seems reasonable to her. And this is not the only exception to the requirement of justification for belief-acts that the critical rationalist will be forced to make, on thinking the matters through. Rather, there will be no end to such exceptions, as we will see shortly.

The second objection is that if the principle $(\mathrm{CR})$ «It is reasonable to adopt the theory that best survives critical scrutiny» is granted, there arises the problem of the infinite regress of criticizers.

Let us think of the following questions. What should critical scrutiny consist in? How - on what considerations - should we judge that theory A rather that some alternative theory «best survives critical scrutiny»? What are legitimate statements to be used as «criticizers»?

Surely, we can't take any arbitrary statements as equally legitimate, or good, or weighty criticizers, for this would make all alternative theories equally neither-bad-nor-good against critical scrutiny. Should we evaluate criticizers on the same principle, that it is reasonable to adopt criticizers that «best survive critical scrutiny»? But this would require secondlevel-criticizers for the first-level-criticizers, and there is the same problem of justification, or reasons, for adopting the second-level-criticizers, and then third-level-criticizers, and so on ad infinitum. So, we have the infinite regress of criticizers that precisely mirrors the initial problem that Popper's-Bartley's non-justificationism was advanced to solve.

However, is this not helped by the principle $(\mathrm{P} \& \mathrm{~T})$ ? This principle ensures that perceptual and testimentory beliefs can serve as those points where the regress can be stopped; they can be used as criticizers whose credentials are granted by default, even before they themselves undergo critical scrutiny. Does this solve the problem? Unhappily, it does not.

To begin with, how are we to justify our acceptance of the principle $\mathrm{P} \& \mathrm{~T}$ itself? It obviously won't do to say that it is reasonable because it best survives critical scrutiny - we do not yet have any means (criticizers) with which to carry out the scrutiny. It won't also do to say that the conjunction of $(\mathrm{CR})$ and $(\mathrm{P} \& \mathrm{~T})$ is reasonable in its own lights, on its own criteria, as self-subsuming. First, as we have already seen, such a self-subsumption is too cheap to count as justification. Second, there is no way to judge whether the conjunction of $(\mathrm{CR})$ and $(\mathrm{P} \& \mathrm{~T})$ is self-subsuming, that is, best survives criticisms given criticizers of the kind allowed by $(\mathrm{P} \& \mathrm{~T})-$ perceptual and testimentory beliefs. You cannot criticize principles such as 
$(\mathrm{CR})$ and $(\mathrm{P} \& \mathrm{~T})$ with perceptual and testimentory beliefs alone, because no predictions about observable events or human actions or experiences follow from such principles.

Generally, real critical practice, in science as well as outside it, would be impossible without a lot of other considerations that cannot be justified (even in terms of best surviving critical scrutiny) by appeals to perceptual and testimentory beliefs (even as criticizers), such as economy, elegance, common sense, or intuitive sense of plausibility, etc. Besides, various perceptual and testimentory beliefs often conflict with one another, and so one needs to resolve these conflicts, but one cannot do this by mere appeals to some other perceptual and testimentory beliefs. (There is no reason why these other beliefs should be preferred to the initial ones.) At some points of critical discussion, when different considerations conflict, one should just make one's own unjustified judgment.

So, any rational discussion necessarily involves a lot of beliefs that are acquired and held without justification (even in terms of best surviving critical scrutiny), and these beliefs cannot be neatly taken inventory of, and ordered hierarchically. There is no definite legitimate all-purpose foundation for any rational discussion to proceed from. (The belief in some such foundation would be that «commitment» against which Bartley advanced non-justificationism.) Bartley was perfectly clear on this point:

Pancritical rationalist, like other people, holds countless unexamined presuppositions and assumptions, many of which may be false. His rationality consists in his willingness to submit these to critical considerations when he discovers them or when they are pointed out to him [...] When one belief is subjected to criticism, many others, of course, have to be taken for granted - including those with which the criticism is being carried out. The latter are used as the basis of criticism not because they are themselves justified or beyond criticism, but because they are unproblematical at present. These are, in that sense alone and during that time alone, beyond criticism. We stop criticizing - temporarily not when we reach uncriticizable authorities, but when we reach positions against which we can find no criticisms. If criticisms of these are raised later, the critical process then continues. ${ }^{34}$ (Italics mine)

${ }^{34}$ Bartley $W$. The Retreat to Commitment. - P. 121-122.

See also Mark Notturno's explanation:

Critical thinkers [...] question and test the beliefs that others take for granted. In so doing, they oftentimes clarify how some of their beliefs are based upon others. But this basing of beliefs one upon another must ultimately end. And if you are a critical thinker, then you will, somewhere in the course of your tests, inevitably come upon statements that you believe for no other reason than that they seem true - to you. In such a case, it 


\section{Popper's-Bartley's non-justificationism: critical discussion without unrevisable foundations}

To put things in a nutshell, the non-justificationist (comprehensively critical) rationalism is the response to the challenge of what may be called «the commitment argument». The commitment argument is that, because of the problem of the infinite justificatory regress (or vicious circularity), the following holds: (1) in our reasoning (arguing) we inevitably ultimately appeal to some positions that are not supported by further reasons (arguments) but accepted on credence, and (2) therefore, we have no escape but to commit ourselves to these positions, hold them as uncriticizable and unrevisable dogmas. (Comprehensively) critical rationalism meets this challenge by admitting (1) and explaining that (2) does not follow and is false: although any argument appeals to some positions taken as «basic» relative to the argument, these need not be taken as basic in the absolute sense; we may accept them tentatively for a while (as such that seem unproblematic or, at least, credible enough), leaving open the possibility of their problematization and revision as a result of further arguments.

To illuminate the non-justificationist (critical rationalist) conception of rationality, it is useful to compare it with what Musgrave, in the book Common Sense, Science and Scepticism (chapter 1), describes as the answer to the problem of infinite regress by the philosophers he calls «dogmatists» (which include classical rationalists and empiricists). The «dogmatist» answer is based on the distinction between

immediate knowledge, which does not require further justification

and

mediated knowledge, which requires justification by immediate knowledge.

«Dogmatists» differ as to what is the source of immediate knowledge. Some (called «empiricists») believe that it is experience (perceptions), others (called «rationalists» or «intellectualists») - that it is reason (its inherent indubitable ideas). ${ }^{35}$

What is CR's view about immediate knowledge? Does it admit that there is such knowledge? If yes, what kind of knowledge it is, perceptual or inherent to reason?

would be more accurate to say not that such statements are justified, but that they seem, in your judgment, to be true. (Notturno M. Science and the Open Society. - p. 147)

${ }^{35}$ Musgrave A. Common Sense, Science and Scepticism. - P. 13-18. 
I think that it would be correct to say that CR agrees with «dogmatism» that there is «immediate knowledge» that does not require further justification, or argumentative support. And CR admits that there is «immediate knowledge» of both - «empiricist» and «rationalist» - kinds. On the «empiricist» side, it is observational beliefs, on the «rationalist» side, it is logics, common sense, some epistemological assumptions, inborn or learned expectations, basic moral ideas, etc. Immediate knowledge has as its sources experience, inborn expectations, intuition, etc. However, unlike «dogmatism», CR does not dogmatize this «immediate knowledge». CR denies that it is certain or highly probable (in the sense of the probability calculus). CR also denies that it is unrevisable, that there is no way to check and correct it. Instead, CR contends that «immediate knowledge», as well as mediated, is fallible and open to examination, critical discussion and revision.

Besides, on the CR view, there is no neat demarcation between immediate and mediated knowledge. First, there are degrees: for example, in science, an observational statement may be heavily theory-laden and so pretty much mediated, but it is more immediate than the theory that it is intended to test. Second, «immediate knowledge» can be criticized by other - immediate or mediate - knowledge, and can be supported by yet other - immediate or mediate - knowledge. When some points of «immediate knowledge» are challenged, we try to find reasons pro and contra and weigh them up and make our reasoned judgment. And those reasons are just appellations to other - immediate or mediate - knowledge.

Hence, there can be no overall inventory of «immediate knowledge» and the relationships between its components. And «immediate knowledge» has no absolutely «hard core» - ideas and principles which are absolutely basic and, so, beyond the possibility of criticism and revision.

Besides, CR contends that all that «knowledge» is not knowledge in the sense of justified true beliefs - it is conjectural knowledge with no certificate (certainty) of truth or even high probability (in the sense of the probability calculus).

The meaning of Popperian non-justificationism can be yet better understood if we think of the purpose, raison d'etre, of the justificationist enterprise. Why do philosophers traditionally bother so much about justification? Probably, the major motivation comes from the concept of knowledge, as traditionally understood. The standard definition of «knowledge» is «justified true belief». It was Plato who famously emphasized the difference between knowledge and mere true belief: for a person to know that $\mathrm{X}$, it is not enough that the person believed that $\mathrm{X}$ and that 
$\mathrm{X}$ were the case; it is necessary also that the person had sufficient reasons to believe that $\mathrm{X}$, that is, was justified in believing that $\mathrm{X}$. If a person has a belief without sufficient reasons, and that belief happens to be true by accident, the person does not really know. Now, for many centuries after Plato, up to the present day, most philosophers concerned with knowledge believed that this distinction - between knowledge and accidentally true belief - is of supreme importance. Hence, they searched for the right way to draw such a distinction: what should count as sufficient reasons? A lot of different theories were proposed and opposed one another, and it seems that there is no way to adjudicate between them impartially, except to admit that they all are unsatisfactory because they fail to satisfy their own requirement of being justified, except in a question-begging way (relative to their own criteria). If so, the enterprise of justification looks hopeless, and one can understand why it is so by merely thinking through the logical situation - the problem of infinite justificatory regress that «must, for logical reasons, be terminated by an arbitrary and irrational appeal to what can be called dogmas or absolute presuppositions». ${ }^{36}$ The alternative to such dogmatic commitment is to discard the justificationist enterprise - the project of epistemology guided by Plato's distinction between knowledge as justified true belief and mere true belief. (Here, it is appropriate to recollect Popper's "provocative" claim that the best of the knowledge we have, scientific knowledge, is not knowledge: it is not composed of justified true beliefs. ${ }^{37}$ )

However, discarding justificationism does not mean discarding reasons. It does not even mean that any claim that a theory or a belief is justified is false. In ordinary language, one can talk of (tentative) justification in the sense of providing arguments in favor of a position, or explaining reasons why one holds or prefers it. ${ }^{38}$ Nothing is wrong with such a «justification»; however, we must be aware that it cannot bear anything like the burden that justification is traditionally (in particular, by Plato and Hume) required to bear.

It is worth noting that such a «justification-in-ordinary-language», or substantiation, or argumentative support, besides being tentative, has a

\footnotetext{
${ }^{36}$ Bartley $W$. The Retreat to Commitment. - p. 221.

${ }^{37}$ Popper K. Realism and the Aim of Science. - pp. 12-13.

${ }^{38}$ Popper admitted that «giving reasons for one's preference can of course be called a justification (in ordinary language)», and added the reservations that «it is not a justification in the sense criticized here», and that «our preferences are "justified" only relative to the present state of our discussion» (Ibid. - p. 20). He also conceded that «to have some "foundation", or justification, may be important for a belief» but it should not be required of scientific hypotheses (Ibid. - p. 22).
} 
«more-or-less» rather than «either-or» character. Instead of dividing positions into justified and unjustified, we evaluate the balance of reasons pro and contra as more-or-less favoring-or-disfavoring the position at issue. And this makes us accept or decline the position (as likely to be true or a good enough approximation to the truth) tentatively, without committing ourselves to its truth or falsity, leaving widely open the possibility of revision.

If my construal is right, Popperian non-justificationism can be «positively» redescribed as «evaluationism»: its point is that we should be interested in evaluation of arguments (in terms of validity, soundness, and weightiness) and positions (in terms of truth, falsity and verisimilitude), and do not bother about justification. Justificationism makes for a defensive attitude that is not conductive to the development of knowledge; it is as if our beliefs are accused of being non-legitimate, or we are accused of holding such non-legitimate beliefs, and now we are expected to justify them, or ourselves. Unlike this, evaluationist attitude is explorative: we try to find out reasons (arguments) pro and contra a position at issue, evaluate their strength and balance, and, as a result, tentatively accept or decline the position.

Note, that the above-mentioned defensive attitude makes no sense, because belief-acquiring or belief-holding (believing that $\mathrm{X}$ is the case) is not a matter of deliberate choice, and so requires no justification. We believe something because we are led to believe it by our experiences and various considerations and arguments we had encountered - not because we have chosen to believe it. A person cannot decide that from suchand-such a moment she will start believing such-and-such a proposition, and implement the decision. If so, a person cannot be reasonably held responsible for her beliefs, and the idea that we need to justify our beliefs makes no sense. However, a person can be reasonably invited to consider the arguments (reasons) for and against a position, which may result in changes in the person's beliefs.

\section{References}

[1] Bartley $W$. The Retreat to Commitment. - La Salle, Illinois: Open Court, 1984.

[2] Bartley W. Unfathomed Knowledge, Unmeasured Wealth. - La Salle, Illinois: Open Court, 1990. 
[3] Law S. Philosophy Gym. - London: Headline Review, 2004.

[4] Law S. The Great Philosophers. - London: Quercus, 2007.

[5] Miller D. Critical Rationalism: A Restatement and Defense. - La Salle, Illinois: Open Court, 1994.

[6] Miller D. Out of Error. Further Essays on Critical Rationalism. Aldershot: Ashgate, 2006.

[7] Musgrave A. Common Sense, Science and Scepticism. - Cambridge University Press, 2000.

[8] Musgrave A. How Popper [Might Have] Solved the Problem of Induction // Philosophy. - 2004. - Vol. 79 (1). - P. 19-31.

[9] Musgrave A. Critical Rationalism // E.Suárez-Iñiguez, ed., The Power of Argumentation. - Amsterdam/New York : Rodopi, 2007. - P. 171211.

[10] Musgrave A. Experience and Perceptual Belief // S. Parusnikova and R.S. Cohen (eds). Rethinking Popper. - Dordrecht: Springer Science and Business Media, 2009. - P. 5-19.

[11] Notturno M. Science and the Open Society. - Central European University Press, 1999.

[12] Papineau D. Review of Popper and After by David Stove // Times Literary Supplement. - 1983. - July 1.

[13] Papineau D. Review of Knowledge and the Body-Mind Problem and The Myth of the Framework by Karl Popper // Times Literary Supplement. - 1995. - June 23.

[14] Popper K. The Logic of Scientific Discovery. - London: Hutchinson, 1959.

[15] Popper K. Conjectures and Refutations. - New York: Basic Books, 1962.

[16] Popper K. Realism and the Aim of Science. - London: Hutchinson, 1983.

[17] Popper K. In Search of a Better World. - London and New York: Routledge, 1992. 
[18] Stove D. Popper and After: Four Modern Irrationalists. - Oxford, New York: Pergamon Press, 1982.

Надійшла до редакиії 16 липня 2020 р.

Сепетий Дмитро Петрович

Кафедра суспільних дисциплін

Запорізький державний медичний університет

пр. Маяковського, 26

м. Запоріжжя

69035

\section{Sepetyi Dmytro}

Department of Social Disciplines

Zaporizhzhia State Medical University

Mayakovskogo ave., 26

Zaporizhzhia

69035

(iD https://orcid.org/0000-0003-2110-3044

@ dmitry.sepety@gmail.com

doi $10.31812 /$ apd.v0i21.3873 